\title{
Experimental Study on Concrete Specimens Strengthened with Non-woven Plastic Sheets
}

\author{
Sifatullah Bahij 12, Safiullah Omary', Vincent Steiner ${ }^{1}$, Francoise Feugeas ${ }^{1}$, Amanullah Faqiri' ${ }^{2}$ \\ ${ }^{1}$ Icube, UMR CNRS 7357, INSA Strasbourg, 24 Boulevard de la Victoire, 67084, University of Strasbourg, France \\ sifatullah.bahij@insa-strasbourg.fr; safiullah.omary@insa-strasbourg.fr; vincent.steiner@insa-strasbourg.fr; \\ francoise.feugeas@insa-strasbourg.fr \\ 2Department of Civil and Industrial Construction, Kabul Polytechnic University, Kabul, Afghanistan \\ engafaqiri@gmail.com
}

\begin{abstract}
The annual consumption of plastics has been increasing gradually and resulting in a huge amount of plastic waste. The inappropriate disposal of plastic causes many environmental problems due to the shortage of space for landfilling and low biodegradability. Therefore, one possible solution is to recycle and reuse plastic wastes in the construction industry. The objective of this research is to investigate the possibility of evolon ${ }^{\circledR}$ non-woven plastic textile for strengthening concrete specimens. Hence, an experiment was carried out to investigate certain properties of the ordinary concrete strengthened by the layers of non-woven plastic tissue. For this purpose, concrete specimens with five various configurations; no sheets (Ref), one layer at the bottom (1Layer), samples strengthened at two vertical sides (2-Sides), sheets at the bottom and two vertical sides (3-Sides), and full wrapping (4-Sides) were cast and tested. The cubical and cylindrical compressive strengths, flexural strength, and split tensile strength tests were measured after 7,14 , and 28 days of curing, while ultrasonic pulse velocity (UPV) and thermal conductivity values were calculated only after 28 days of curing. The findings clearly demonstrate that the mechanical properties of strengthened samples (compressive, flexural, and split tensile strengths) were improved significantly compared to the control ones at each curing regime. Moreover, it was obtained that the attachment of non-woven sheets alters the failure mechanism from very brittle to much ductile. Besides, non-woven sheets had the capacity to maintain the samples from deterioration into many portions as was observed for reference samples after mechanical testing. Finally, the attachment of such sheets resulted in the reduction of UPV and thermal conductivity of concrete samples compared to the control ones. Therefore, nonwoven fabrics are recommended to improve certain properties of concrete.
\end{abstract}

Date Received: 2021-06-02

Date Accepted: 2021-06-06

Date Published: 2021-06-23
Keyword: Evolon ${ }^{\circledR}$ non-woven sheets, Mechanical properties, Failure mechanism, Ultrasonic pulse velocity, Thermal conductivity

(C) Copyright 2021 Authors - This is an Open Access article published under the Creative Commons Attribution License term (http://creativecommons.org/licenses/by/3.0). Unrestricted use, distribution, and reproduction in any medium are permitted, provided the original work is properly cited.

\section{Introduction}

Recently, the huge amount of low biodegradability plastic wastes resulted in serious challenges to the environment and public health. Therefore, the reuse of plastic wastes could be counted as one of the important ways in sustainable waste management and helps to save natural resources and decrease environmental pollutions [1]-[3]. In total, 348 million tons of plastic were produced worldwide in 2017, with 61.8 million tons only in Europe in the same year. This figure was raised in 2018 to 359 million tons for the entire world and 64.4 million tons for Europe. Besides, plastic production is expected to become double by 2035 and quadruple by 2050 [4]-[7].

There are several options for dealing with this massive volume of plastic wastes, but one viable and practical method is to incorporate plastic waste into cementitious materials. Generally, researchers utilized plastic wastes in two methods as aggregates replacement or as incorporated fibres in cementitious mixtures. In addition, these incorporated materials were derived from polyethylene terephthalate (PET), polypropylene (PP), polyethylene (PE), polyvinyl 
chloride (PVC), polystyrene, etc. [8]. Applications of waste plastic to cementitious materials are common and many researchers have studied the effect of such wastes on various properties of cementitious materials [1], [9][13].

For instance, experimental work was carried out to study the mechanical properties of mortar containing $3 \%, 10 \%, 20 \%$, and $50 \%$ of PET waste aggregates replaced by sand. The researchers revealed that the compressive strength decreased with the increase of the amount of PET plastic aggregates. This drop could be attributed to inadequate cement paste-to-plastic aggregate bonding [12]. In addition, a research study was conducted on concrete specimens having 5\%,10\%, $15 \%$, and $20 \%$ of plastic waste fibres derived from PET bottles and replaced by sand. The results underlined that the flexural strength enhanced up to $10 \%$ replacement of PET fibres and then gradually reduced for $15 \%$ and $20 \%$ replacements [14]. Moreover, it was observed from the research study which was carried out on concrete samples having $0.5 \%, 1.0 \%, 1.5 \%$, and $2.0 \%$ of PET fibres that the split tensile strength enhanced significantly with the increase of PET fibres percentage up to $1.5 \%$, but afterward, slightly decreased [15].

Furthermore, the sound transfer velocity of selfcompacting mortar containing $0 \%, 10 \%, 20 \%, 30 \%$, and $50 \%$ of plastic wastes from bags manufacturers replaced by fine aggregates was experimentally investigated. The outcomes present a remarkable reduction in sound velocity when fine aggregates were replaced by plastic wastes at each curing regime. This is due to the lower sound velocity in plastic waste compared to the concrete ingredients [11]. Likewise, a research study was carried out to explore the effect of various types of plastic fibres on thermal conductivity $(\mathrm{k})$ of concrete. It was underlined that the thermal conductivity has decreased considerably with the incorporation of plastic fibres compared to the control specimens. This can be due to the lower thermal conductivity of plastic fibres than cement and aggregates. However, this reduction was more significant for the mixtures containing polypropylene (PP) compared to the polyethylene terephthalate (PET) [8].

It has been summarized from the literature that researchers have conducted adequate studies on plastic wastes that have been substituted by aggregates or added to concrete mixtures. However, none of the authors considered using recycled plastic wastes as a layer to reinforce concrete samples. Therefore, this research study aims to investigate the mechanical, sound, and thermal properties of normal concrete containing evolon $₫$ non-woven textiles as a layer with different configurations, and their results were compared.

\section{Experimental Work \\ 2.1. Materials}

An Ordinary Portland Cement named GHORI produced by Pole-Khomri Company inside Afghanistan according to the standard of ASTM C150 [16] was used for the preparation of concrete specimens. This cement had a specific gravity of 3.041 and a Blaine surface area of $2900 \mathrm{~cm} 2 / \mathrm{gr}$. Moreover, the chemical composition of GHORI cement is presented in Table 1.

Table 1. Chemical composition of GHORI cement

\begin{tabular}{cc} 
Components & Weight (\%) \\
\hline $\mathrm{CaO}$ & 63.44 \\
$\mathrm{SiO}_{2}$ & 17.63 \\
$\mathrm{Al}_{2} \mathrm{O}_{3}$ & 4.90 \\
$\mathrm{Fe}_{2} \mathrm{O}_{3}$ & 2.01 \\
$\mathrm{~K}_{2} \mathrm{O}$ & 0.57 \\
$\mathrm{MgO}$ & 1.33 \\
$\mathrm{Na} 2$ & 1.37 \\
$\mathrm{~S}--$ & 1.69 \\
$\mathrm{Cl}-$ & 0.01 \\
$\mathrm{SO}_{3}$ & 4.21 \\
\hline
\end{tabular}

Furthermore, the concrete mixture included two types of crushed coarse aggregates as well as natural river sand as fine aggregates. Coarse aggregates had maximum sizes of $10 \mathrm{~mm}$ and $25 \mathrm{~mm}$, whereas fine aggregates had a maximum size of $6.3 \mathrm{~mm}$. Besides, size distribution observed from sieve analysis and other physical properties of both fine and coarse aggregates are shown in Figure 1 and Table 2. 


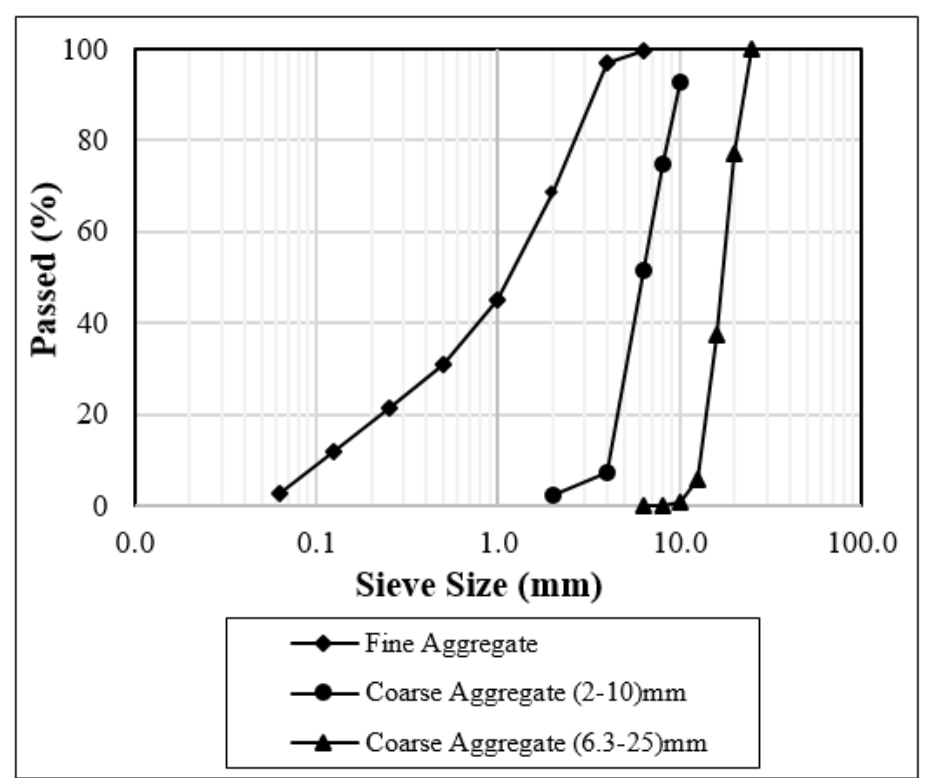

Figure 1. Size distribution of coarse and fine aggregates

Table 2. Physical properties of coarse and fine aggregates

\begin{tabular}{|c|c|c|c|}
\hline \multirow{2}{*}{$\begin{array}{c}\text { Types of } \\
\text { aggregates }\end{array}$} & $\begin{array}{c}\text { Specific } \\
\text { gravity }\end{array}$ & $\begin{array}{c}\text { Water } \\
\text { absorption } \\
\text { (\%) }\end{array}$ & $\begin{array}{c}\text { Bulk } \\
\text { density } \\
\text { (kg/m } \mathbf{~})\end{array}$ \\
\hline Fine aggregate & 2.653 & 1.051 & 1624.52 \\
\hline $\begin{array}{c}\text { Coarse aggregate } \\
(2-10) \text { mm }\end{array}$ & 2.634 & 1.442 & 1288.90 \\
\hline $\begin{array}{c}\text { Coarse aggregate } \\
(6.3-25) \text { mm }\end{array}$ & 2.586 & 1.128 & 1299.98 \\
\hline
\end{tabular}

In addition, the superplasticizer named ADUIM 150 sourced from a local Isomat supplier and certified by EN 934-2 [17] was added into concrete mixtures. This superplasticizer was brown in colour and with a density of $1.03-1.07 \mathrm{~kg} / \mathrm{lit}$ and $\mathrm{pH}$ of $5.0 \pm 0.5$.

Finally, evolon $\AA^{\circledR}$ non-woven tissue or textile from FREUDENBERG Company which was produced through splitting, entangling, and bonding by higher water pressure jets was applied in all concrete samples. The result is a unique technical textile with a microfilament structure that provides woven-like mechanical strength and softness as shown in Figure 2. In addition, such sheets are flat, porous, very strong and isotropic, have similar properties in any direction, good mechanical, durability, sound absorption, and thermal insulation properties, etc.

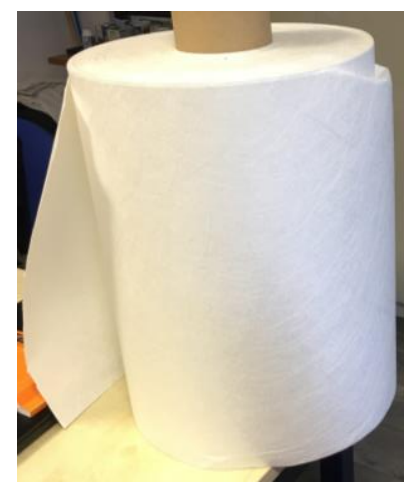

Figure 2. Non-woven plastic tissue [18]

\subsection{Mix Design}

The mix proportion of concrete ingredients is designed based on the ACI Standard Practice, ACI 291.1 [19] (volume basis) that contains a constant w/c ratio of 0.45 and a total binder content of $455 \mathrm{~kg} / \mathrm{m} 3$. The detailed amount of concrete components are summarized in Table 3.

Table 3. Mix proportion of concrete

\begin{tabular}{cc}
\hline Materials & $\begin{array}{c}\text { Weight of } \\
\text { Materials }\left(\mathbf{k g} / \mathbf{m}^{3}\right)\end{array}$ \\
\hline Cement & 455 \\
Water & 205 \\
Sand & 782 \\
Coarse Aggregate & 358 \\
$\begin{array}{c}\text { (2-10) mm } \\
\text { Coarse Aggregate } \\
\text { (6.3-25) mm }\end{array}$ & 538 \\
Superplasticizer & 4.6 \\
\hline
\end{tabular}

\subsection{Specimens Preparation}

In order to cast the samples, the moulds were oiled to make demolding easier, and non-woven plastic tissues were put in the moulds according to their configurations, as presented in Table 4 . The concrete mixtures were prepared using a tilting drum mixer by introducing concrete ingredients into a mixer in proper order. Concrete was poured into the moulds after the mixing was finished and compacted using a vibrating mechanism. Afterward, the samples were kept in the moulds for 24 hours, then demolded, and eventually cured in a curing tank for up to 28 days at a normal temperature of $(20 \pm 2) \mathrm{C}^{\circ}$. 
Table 4. Samples configuration and description

\begin{tabular}{|c|c|c|c|}
\hline $\begin{array}{c}\text { Type and } \\
\text { dimensions } \\
\text { of samples }\end{array}$ & Name & Description & $\begin{array}{l}\text { Conducted } \\
\text { tests }\end{array}$ \\
\hline \multirow{4}{*}{$\begin{array}{c}\text { Cube } \\
100 \mathrm{~mm}\end{array}$} & Ref & No sheet & \multirow{4}{*}{$\begin{array}{c}\text { Compressive } \\
\text { strength and } \\
\text { UPV }\end{array}$} \\
\hline & 1-Layer & $\begin{array}{l}\text { A layer of non- } \\
\text { woven sheet at } \\
\text { the bottom }\end{array}$ & \\
\hline & 2-Sides & $\begin{array}{c}\text { Non-woven } \\
\text { sheets at two } \\
\text { vertical } \\
\text { opposite sides }\end{array}$ & \\
\hline & 4-Sides & $\begin{array}{c}\text { Non-woven } \\
\text { sheets at all } \\
\text { four vertical } \\
\text { sides }\end{array}$ & \\
\hline \multirow[b]{2}{*}{$\begin{array}{c}\text { Cylinder } \\
(100 \times 200) \\
\mathrm{mm}\end{array}$} & Ref & No sheet & \multirow[b]{2}{*}{$\begin{array}{l}\text { Compressive } \\
\text { and split } \\
\text { tensile } \\
\text { strengths }\end{array}$} \\
\hline & Layer & $\begin{array}{l}\text { Completely } \\
\text { covered with } \\
\text { non-woven } \\
\text { sheets }\end{array}$ & \\
\hline \multirow{4}{*}{$\begin{array}{c}\text { Beam } \\
(100 \times 100 \times 5 \\
00) \mathrm{mm}\end{array}$} & Ref & No sheet & \multirow{4}{*}{$\begin{array}{l}\text { Flexural } \\
\text { strength }\end{array}$} \\
\hline & 1-Layer & $\begin{array}{l}\text { A layer of non- } \\
\text { woven sheet at } \\
\text { the bottom }\end{array}$ & \\
\hline & 2-Sides & $\begin{array}{c}\text { Non-woven } \\
\text { sheets at two } \\
\text { vertical } \\
\text { opposite sides }\end{array}$ & \\
\hline & 3-Sides & $\begin{array}{l}\text { Non-woven } \\
\text { sheets at two } \\
\text { vertical } \\
\text { opposite sides } \\
\text { and bottom }\end{array}$ & \\
\hline \multirow{3}{*}{$\begin{array}{c}\text { Cylinder } \\
(100 \times 70) \\
\mathrm{mm}\end{array}$} & Ref & No sheet & \multirow{3}{*}{$\begin{array}{c}\text { Thermal } \\
\text { conductivity }\end{array}$} \\
\hline & 1-Layer & $\begin{array}{l}\text { A layer of non- } \\
\text { woven sheet at } \\
\text { one face }\end{array}$ & \\
\hline & 2-Sides & $\begin{array}{l}\text { A layer of non- } \\
\text { woven sheet at } \\
\text { two faces }\end{array}$ & \\
\hline
\end{tabular}

\section{Results And Discussions}

\subsection{Fresh Properties}

The workability of concrete mixtures was determined using the ASTM C143 code guidelines [20]. Since non-woven fabrics were used as a layer with different configurations at the specimens' outer faces, therefore, the same mix design was used for all samples and configurations. It means that such sheets did not have any effect on the workability and homogeneity properties of concrete mixtures. However, the average slump value of concrete mixtures prepared based on the above mix design was observed as $158 \mathrm{~mm}$ with no segregation and bleeding. In addition, the utilization of such sheets had no effect on the fresh density of concrete as well. The average fresh density of concrete mixtures prepared based on the above mix proportion and ingredients was $2680.4 \mathrm{~kg} / \mathrm{m} 3$.

\subsection{Mechanical Properties}

\subsubsection{Compressive Strength}

ASTM C39 [21] standard was used to determine the compressive strength of cube and cylindrical specimens. The results of cube compressive strength and their comparison after 7, 14, and 28 days of curing are shown in Figure 3a and Table 5. The findings indicate that applying layers has a minor effect on the cube compressive strength. Whereas the compressive strength has increased slightly, while cube samples were covered by non-woven sheets with different configurations. However, as compared to the control specimens, the compressive strength of cylindrical specimens covered with non-woven textile improved significantly as presented in Figure $3 \mathrm{~b}$ and Table 5. For instance, at 28 days of curing, the compressive strength of cubical samples strengthened with 1-Layer, 2-Sides, and 4 -Sides configurations enhanced by $2.5 \%, 4.7 \%$, and $6.8 \%$, respectively, compared to the references ones. While at the same curing time, the cylindrical compressive strength was enhanced by $13.4 \%$ for the wrapped samples compared to the control ones. This is due to the ability of non-woven sheets to restrain cracks extension, alter cracking direction and delay cracking growth rate, therefore, more energy is required for the propagation of cracks inside samples and samples failure.

Table 5. Compressive strength after different curing regimes

\begin{tabular}{ccccc}
\hline \multirow{2}{*}{$\begin{array}{c}\text { Type of } \\
\text { sample }\end{array}$} & \multirow{2}{*}{ Name } & \multicolumn{3}{c}{ Compressive strength (MPa) } \\
\cline { 3 - 5 } & & $\mathbf{7}$ days & 14 days & 28 days \\
\hline \multirow{4}{*}{ Cube } & Ref & 17.25 & 21.16 & 29.81 \\
& 1-Layer & 18.85 & 22.78 & 30.55 \\
& 2-Sides & 18.90 & 22.79 & 31.21 \\
& 4-Sides & 19.25 & 22.95 & 31.84 \\
\hline \multirow{2}{*}{ Cylinder } & Ref & 13.30 & 18.90 & 25.54 \\
& Layer & 15.80 & 21.72 & 28.95 \\
\hline
\end{tabular}




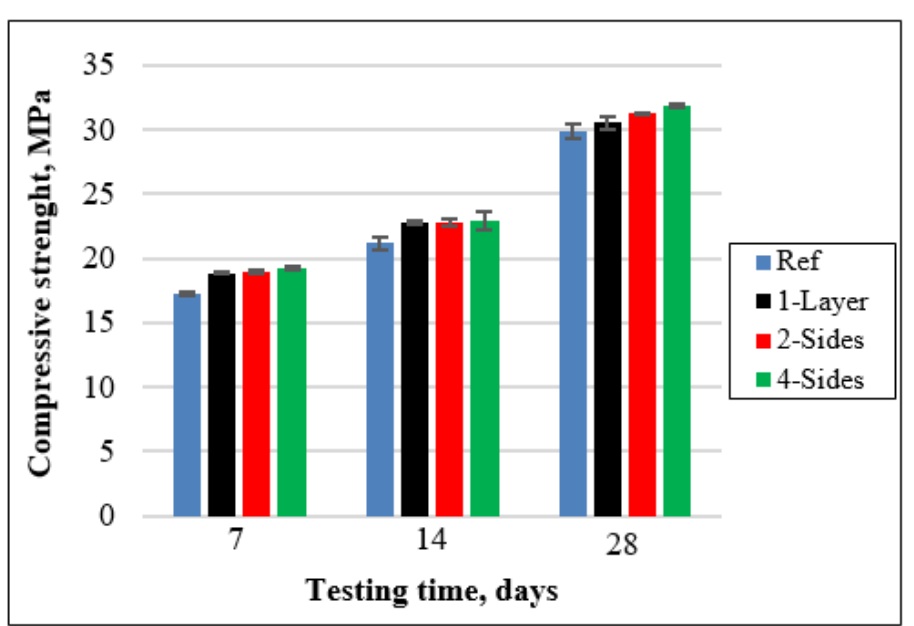

$a$

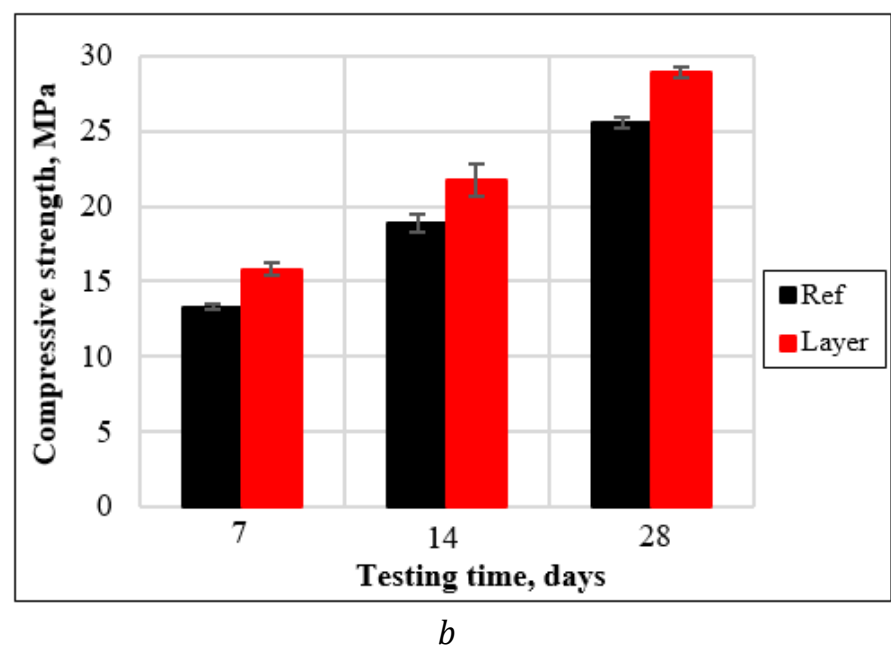

Figure 3. a) Cubical compressive strength, and b) cylindrical compressive strength

The cracking mechanisms illustrate that the control specimens were deteriorated into many portions, whereas the specimens strengthened by 1 Layer, 2-Sides, and 4-Sides configurations were not separated into many pieces but were taken by such layers, especially the faces which were strengthened by the layer as shown in Figure 4. In the case of cylindrical samples, a non-woven plastic sheet is particularly important in preventing separation as shown in Figure 5. This behaviour of non-woven textiles may be more advantageous in the case of sudden failure especially earthquake damages. It indicates that during an earthquake, building elements reinforced with such sheets will be safer than components without nonwoven tissue.
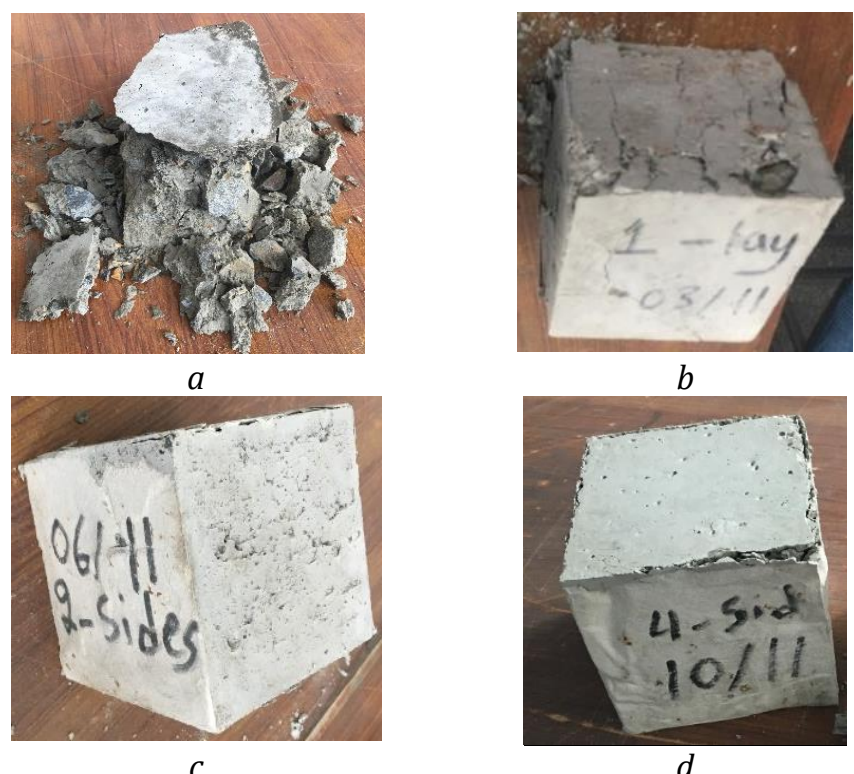

$b$

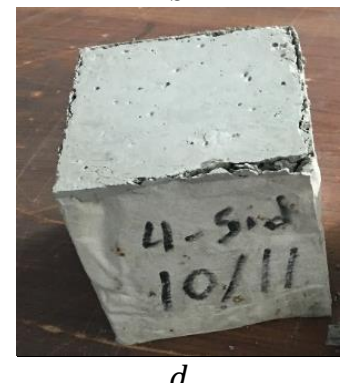

Figure 4. Cracking pattern after the cubical compression test a) Ref, b) 1-Layer, c) 2-Sides, and d) 4-Sides

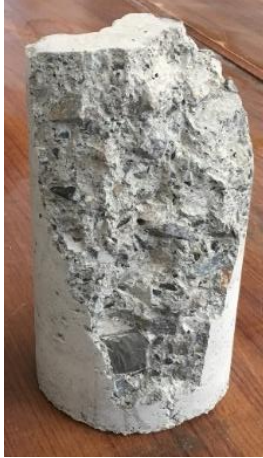

$a$

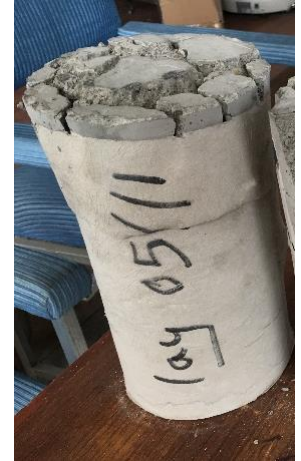

$b$
Figure 5. Cracking pattern after the cylindrical compression test a) Ref and b) covered samples

\subsubsection{Flexural strength}

The flexural test was conducted on beam samples in accordance with ASTM C78 [22]. The findings are shown in Figure 6 and Table 6 and reported that the flexural strength has enhanced remarkably for the strengthened beams compared to the control ones. The outcomes clearly revealed that after 28 days of curing, the flexural strength improved by $12.42 \%, 20.26 \%$, and $34.64 \%$ for the beams having non-woven fabrics at 1 Layer, 2-Sides, and 3-Sides, respectively, compared to the references ones. This is due to the fact that nonwoven sheets act as strengthening materials, causing crack propagation to be delayed and more force to be required for beam damage. Furthermore, the 3-Sides strengthened beams had the highest ultimate load capacity followed by 2 -Sides and 1-Layer. 
Table 6. Flexural strength after different curing regimes

\begin{tabular}{cccc}
\hline \multirow{2}{*}{ Name } & \multicolumn{3}{c}{ Flexural strength (MPa) } \\
\cline { 2 - 4 } & $\mathbf{7}$ days & 14 days & 28 days \\
\hline Ref & 1.77 & 2.17 & 3.06 \\
1-Layer & 2.12 & 2.57 & 3.44 \\
2-Sides & 2.24 & 2.69 & 3.68 \\
3-Sides & 2.45 & 2.97 & 4.12 \\
\hline
\end{tabular}

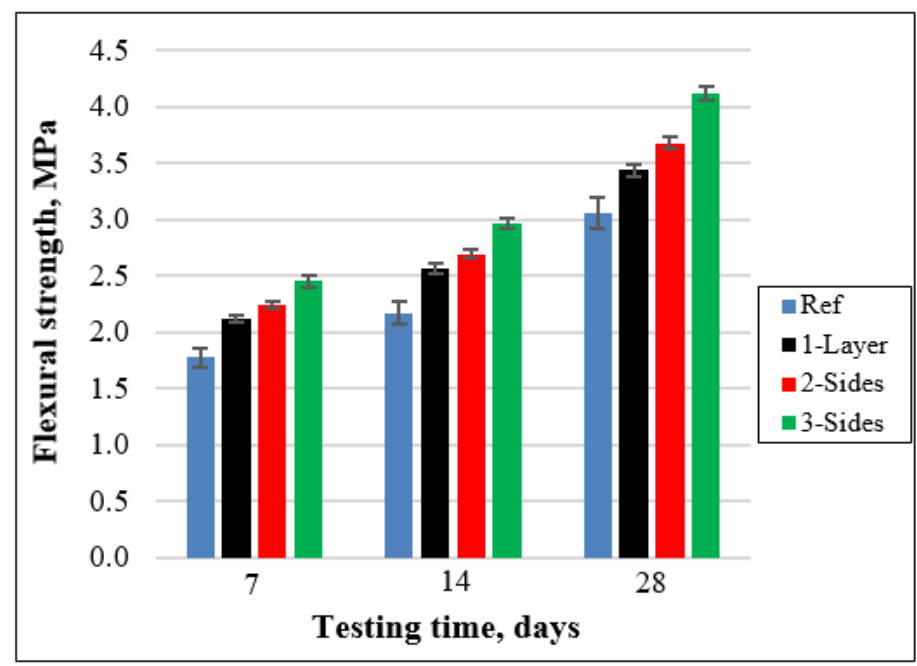

Figure 6. Flexural strength of concrete specimens

Moreover, the cracking pattern for all strengthened beams was similar to the control specimens, where, flexural fractures originated in the mid-span between two loading points, propagated to the depth of the beams, and then being followed by a single widening crack up to the ultimate failure. As a comparison, control beams were failed suddenly and split into two sections at the ultimate loading. Beams with one layer, two sides, and three sides of non-woven sheets were broken but not separated into two pieces, and were taken by the layers of non-woven sheets. Furthermore, control beams had wider cracks, but nonwoven sheet-strengthened beams had narrower cracks, as shown in Figure 7.

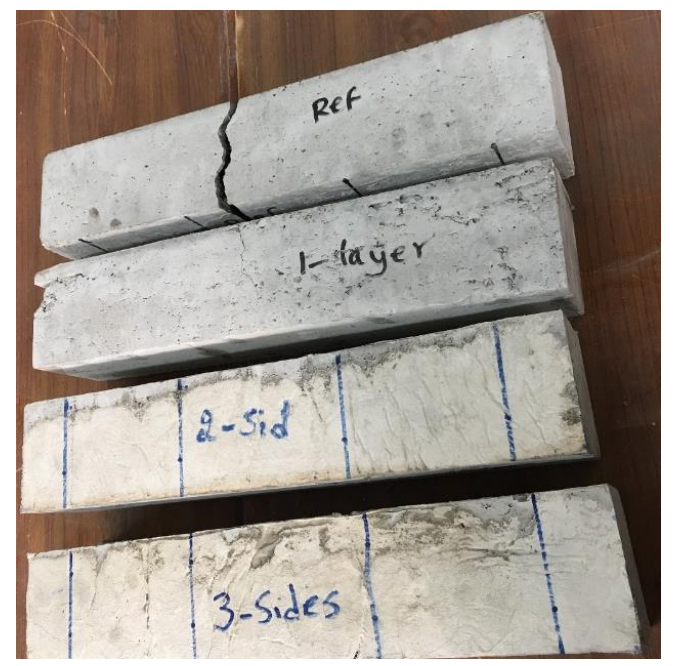

Figure 7. Cracking pattern after flexural loading

\subsubsection{Split tensile strength}

The split tensile strength was performed according to ASTM C496 code considerations [23]. The outputs of the splitting tensile strength are shown in Figure 8 and Table 7 . The results indicate that after 7, 14, and 28 days of curing, the split tensile strength of cylinders wrapped with non-woven sheets is much higher than that of the non-covered specimens. Reference samples showed a split tensile strength of 1.99 MPa after 28 days, while this strength was raised by $16.6 \%$ to $2.32 \mathrm{MPa}$ for covered specimens. This is due to the non-woven sheets bridging the cracks and preventing early damage to the samples, necessitating more energy to fail the samples.

Table 7. Split tensile strength after different curing regimes

\begin{tabular}{cccc}
\hline \multirow{2}{*}{ Name } & \multicolumn{3}{c}{ Split tensile strength (MPa) } \\
\cline { 2 - 4 } & $\mathbf{7}$ days & 14 days & $\mathbf{2 8}$ days \\
\hline Ref & 1.49 & 2.11 & 2.63 \\
Layer & 1.80 & 2.45 & 3.03 \\
\hline
\end{tabular}




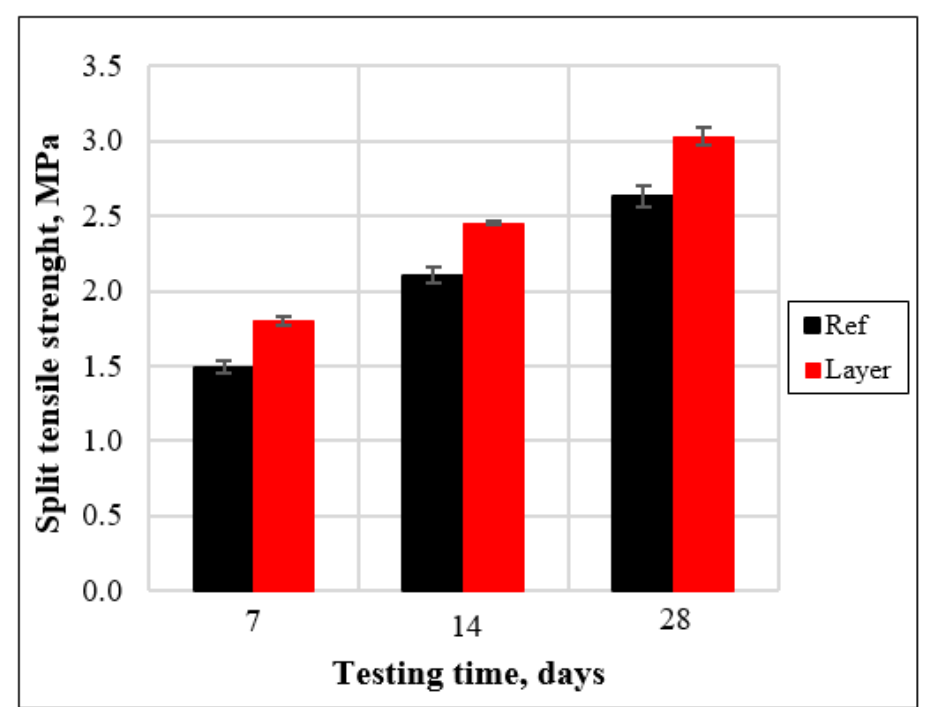

Figure 8. Split tensile strength of concrete specimens

Furthermore, under the tensile splitting test, the reference cylinders failed by brittle fracture, and the specimens were divided into two separate parts. While covered specimens were not damaged into two separate portions but were taken by the sheets. This indicates that with the attachment of plastic sheets, the samples can withstand higher splitting stresses and the ultimate fracture will be free of brittle behaviours as shown in Figure 9. These outputs indicate that when structural elements are subjected to such loads, they can be protected from catastrophic failure with the help of nonwoven sheets.

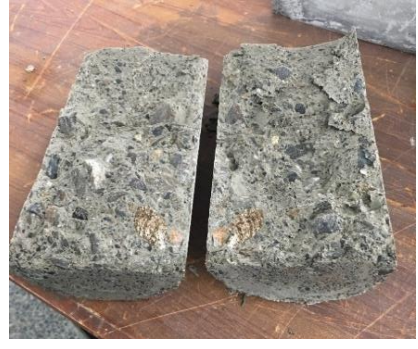

$a$

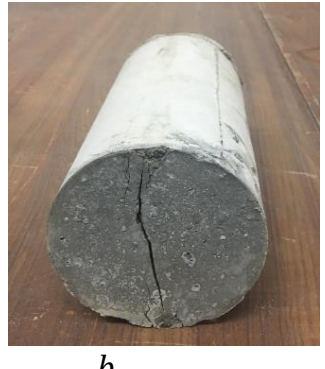

$b$
Figure 9. Cracking pattern after split tensile strength a) Ref and b) covered samples

\subsection{Acoustic properties}

The ultrasonic pulse velocity means to measure the transit time of ultrasonic pulses from concrete and be influenced by the density and elastic properties of concrete. The UPV test was carried out using the direct method in accordance with ASTM C597 standards [24]. The findings of the UPV test are shown in Figure 10 and Table 8. It was documented that the attachment of nonwoven sheets on concrete samples led to decrease the value of UPV compared to the reference samples. It was proven that attaching non-woven sheets to concrete samples reduced the UPV value when compared to the control specimens. After 28 days of curing the UPV value decreased by $12.25 \%$ and $25 \%$ for the specimens containing non-woven sheets at one side and two sides, respectively, compared to the control ones. This can be attributed to the lower UPV value of plastic and sound absorbing behaviours of non-woven sheets compared to the concrete mixtures.

Table 8. UPV value for concrete specimens after 28 days

\begin{tabular}{cc}
\hline Name & UPV (m/s) \\
\hline Ref & 4647.6 \\
1-Layer & 4077.7 \\
2-Sides & 3827.5 \\
\hline
\end{tabular}

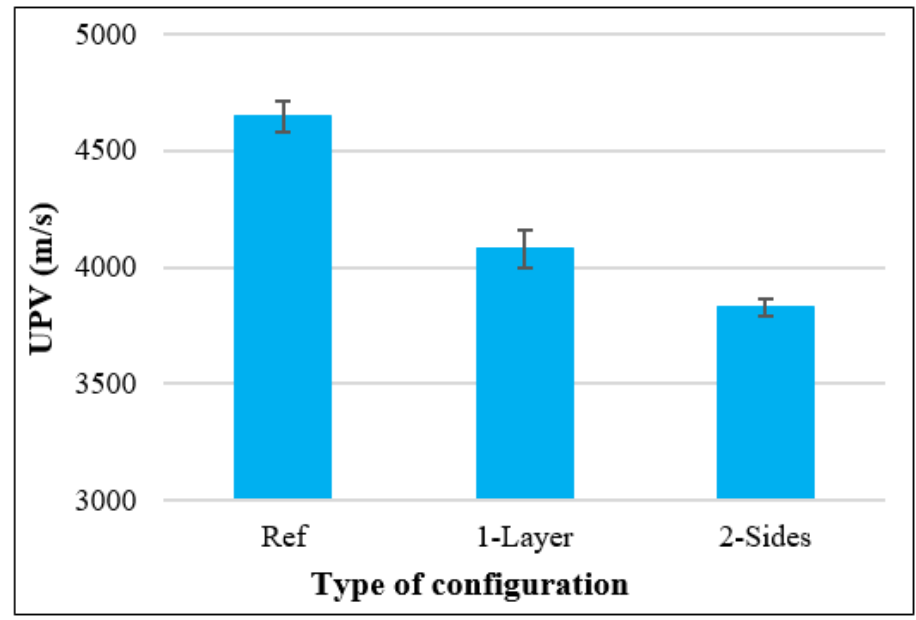

Figure 10. Ultrasonic pulse velocity of concrete

\subsection{Thermal properties}

The thermal conductivity of concrete $(\lambda)$ is one of the most important parameter for understanding the amount of heat transfer by conduction. The amount of heat transfer or thermal conductivity was measured using the equipment of ISOMET 2104 heat transfer analyser. The use of non-woven PET textiles on concrete examples led to a reduction in the amount of heat transfer when compared to the control specimens. After 28 days of curing the thermal conductivity $(\lambda)$ decreased by $9.83 \%$ and $19.67 \%$ for the specimens containing nonwoven sheets at one side and two sides, respectively, compared to the control ones as presented in Figure 11 and Table 9. This is due to the fact that the heat transfer in plastic is less than in concrete mixtures. 
Table 9. Thermal conductivity of concrete specimens after 28 days

\begin{tabular}{cc}
\hline Name & $\begin{array}{c}\text { Thermal conductivity } \\
(\mathbf{w} / \mathbf{m k})\end{array}$ \\
\hline Ref & 0.261 \\
1-Layer & 0.235 \\
2-Sides & 0.210 \\
\hline
\end{tabular}

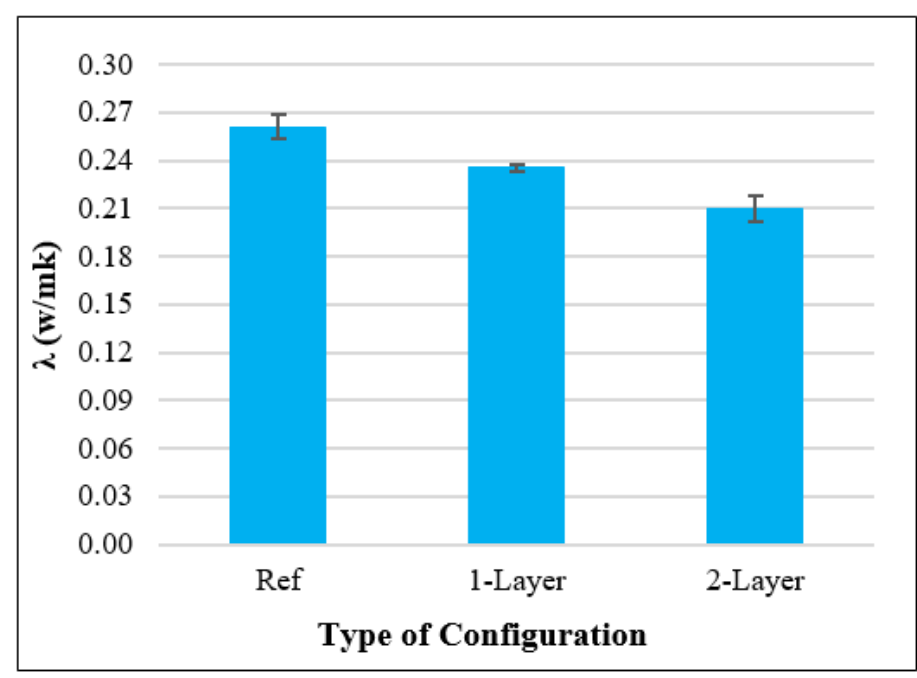

Figure 11. Thermal conductivity of concrete

\section{Discussions}

Figure 12 illustrates the relationships between the strengthen configurations and various behaviours of concrete such as cubical compressive strength, flexural strength, thermal conductivity, and UPV. R-squared correlation coefficient measured as an average of compressive strength, flexural strength, UPV, and thermal conductivity is 0.98 , which indicate a good correlation between the certain properties of concrete and number of strengthened faces.

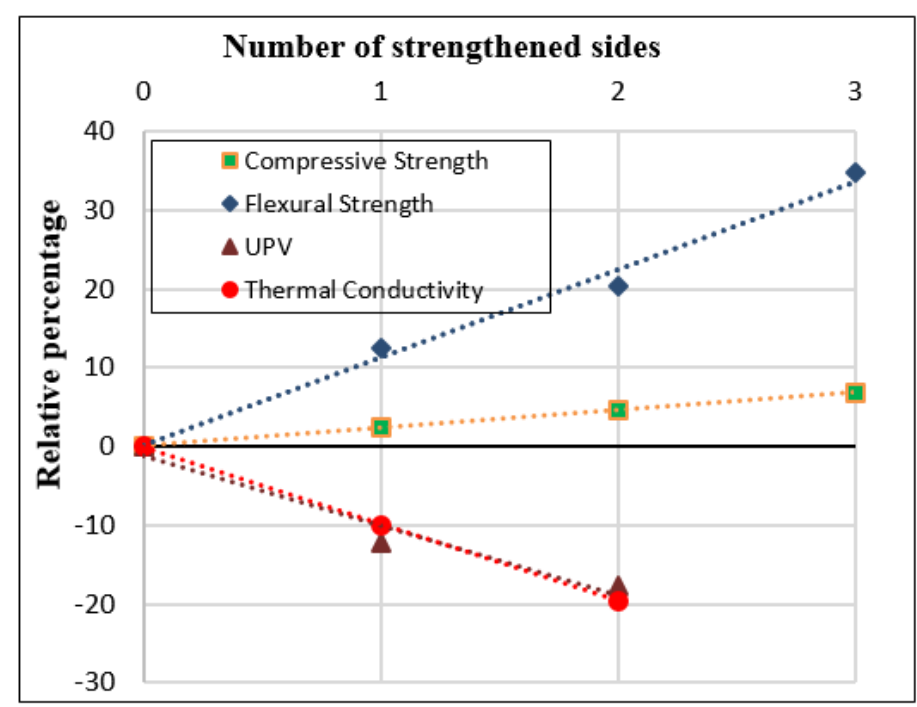

Figure 12. Relations between strengthening configurations and various properties of concrete

\section{CONCLUSIONS}

Based on the outcomes illustrated above, the main concluding points can be described as follows:

- Since non-woven sheets were attached as a layer on the outer faces of specimens, therefore, such fabrics do not have any effect on the workability and fresh density of concrete mixtures.

- The cube compressive strength was slightly enhanced with the attachment of non-woven tissue, whereas such strength improved considerably for the cylindrical samples wrapped by non-woven textile. Moreover, at ultimate compressive load, samples with nonwoven tissue were not separated into many parts like reference ones.

- The flexural strength has remarkably increased for the beams strengthened with 1-Layer, 2Sides, and 3-Sides of non-woven sheets compared to the control ones. In addition, the reference beams failed in a brittle manner and entirely divided into two parts, while the strengthened beams had ductile behaviors during failure and were not divided into two parts but were taken by the sheets.

- It was observed that the splitting tensile strength enhanced significantly for the wrapped cylinders compared to the control ones at all curing regimes. Similar to other mechanical properties, non-covered cylinders were absolutely divided into two separate parts with a brittle failure, while covered samples were taken by non- 
woven tissue after peak load and showed much ductile behaviors.

- The UPV value has decreased significantly for the samples containing layers of non-woven sheets compared to the control ones. The highest UPV value was achieved for the control specimens, while the lowest UPV value was recorded from the samples having non-woven sheets at two opposite sides.

- Finally, it was found that the attachment of nonwoven sheets on concrete specimens was beneficial to enhance the thermal insulation properties of concrete. It means that thermal conductivity decreased remarkably for the specimens with non-woven sheets than the control ones.

\section{REFERENCES}

[1] Z. Z. Ismail and E. A. Al-hashmi, "Use of waste plastic in concrete mixture as aggregate replacement," Waste Management, vol. 28, no. 11, pp. 2041-2047, 2007.

[2] A. I. Al-hadithi and N. N. Hilal, "The possibility of enhancing some properties of self-compacting concrete by adding waste plastic fibers," Journal of Building Engineering, vol. 8, pp. 20-28, 2016.

[3] L. A. Guerrero, G. Maas, and W. Hogland, "Solid waste management challenges for cities in developing countries," Waste Management, vol. 33, no. 1, pp. 220-232, 2013.

[4] M.-L. Franco-García, J. C. Carpio-Aguilar, and H. Bressers, "Towards Zero Waste, Circular Economy Boost: Waste to Resources," Greening of Industry Networks Studies, vol. 6, pp. 1-8, 2019.

[5] B. Mrowiec, "Plastics in the circular economy (CE)," The Journal of Institute of Environmental ProtectionNational Research Institute., vol. 29, no. 4, pp. 16-19, 2018.

[6] M. A. Kamaruddin, M. M. A. Abdullah, M. H. Zawawi, and M. R. R. A. Zainol, "Potential use of Plastic Waste as Construction Materials: Recent Progress and Future Prospect," IOP Conf. Series: Materials Science and Engineering, vol. 267, no. No. $1,2017$.

[7] E. Plastic, "Plastics - the Facts 2019 An analysis of European plastics production, demand and waste data," Available online: https://www.plasticseurope.org/application/files/971 5/7129/9584/FINAL_web_version_Plastics_the_fact s2019_14102019.pdf, 2019.
[8] F. Fraternali, V. Ciancia, R. Chechile, G. Rizzano, L. Feo, and L. Incarnato, "Experimental study of the thermo-mechanical properties of recycled PET fiberreinforced concrete," Composite Structures, vol. 93, no. 9, pp. 2368-2374, 2011.

[9] S. Shahidan et al., "Concrete Incorporated with Optimum Percentages of Recycled Polyethylene Terephthalate (PET) Bottle Fiber," International Journal of Integrated Engineering, vol. 10, no. 1, pp. $1-8,2018$.

[10] K. Akçaözog and C. D. Atis, "Thermal conductivity, compressive strength and ultrasonic wave velocity of cementitious composite containing waste PET lightweight aggregate (WPLA)," Composites : Part $B$, vol. 45, no. 1, pp. 721-726, 2013.

[11] B. Safi, M. Saidi, D. Aboutaleb, and M. Maallem, "The use of plastic waste as fine aggregate in the selfcompacting mortars: Effect on physical and mechanical properties," Construction and Building Materials, vol. 43, pp. 436-442, 2013.

[12] K. Hannawi, W. Prince, and S. Kamali-Bernard, "Effect of thermoplastic aggregates incorporation on physical, mechanical and transfer behavior of cementitious materials," Waste and Biomass Valorization, vol. 1, pp. 251-259, 2010.

[13] P. Fernando, K. M. Oscar Rubem, and R. R. Philippe Jean, Paul Gleizeb Humberto, "Mechanical Properties of Recycled PET Fibers in Concrete," Materials Research, vol. 15, no. 4, pp. 679-686, 2012.

[14] M. Vali and S. S. Asadi, "PET bottle waste as a supplement to concrete fine aggregate," International Journal of Civil Engineering and Technology, vol. 8, no. 1, pp. 558-568, 2017.

[15] B. Sanjaykumar and S. N. Daule, "Use of Plastic Fiber in the Concrete," SSRG International Journal of Civil Engineering (SSRG-IJCE), vol. 4, no. 11, pp. 4-7, 2017.

[16] ASTM C150, "Standard Specification for Portland Cement," American Society for Testing and Materials, 2009.

[17] EN 934-2, "Admixtures for concrete, mortar and grout," European standard, 2012.

[18] Evolon ® microfilament textile, "Innovative microfilament textiles for a wide range of applications. Accessed on 15 March of 2021, on Web site: Freudenberg Innovating Together: https://www.freudenberg-pm.com/Materials/evolon."

[19] ACI 211.1-91, "Standard Practice of Selecting Proportions for Normal, Heavyweight, and Mass Concrete," ACI Manual of Concrete Practice, Part 1: 
Materials and General Properties of Concrete, Detroit, Michigan, 1994.

[20] ASTM C143, "Standard Test Method for Slump of Hydraulic Cement Concrete," American Society for Testing and Materials, 2009.

[21] ASTM C39, "Standard Test Method for Compressive Strength of Cylindrical Concrete Specimens," American Society for Testing and Materials, 2009.

[22] ASTM C78, "Standard Test Method for Flexural Strength of Concrete (Using Simple Beam with ThirdPoint Loading)," American Society for Testing and Materials, 2009.

[23] ASTM C496, "Standard Test Method for Splitting Tensile Strength of Cylindrical Concrete Specimens," American Society for Testing and Materials, 2009.

[24] ASTM C597, "Standard Test Method for Pulse Velocity Through Concrete," American Society for Testing and Materials, 2009. 